\title{
The Effect of Practice Methods on the Ability of Writing Text Complex Procedures of Eleventh Grade Students of Swasta Swadaya Hamparan Perak Senior High School Academic Year 2020-2021
}

\author{
Edy Saputra ${ }^{1}$, Sutikno $^{2, *}$, RatnaWilis ${ }^{1}$, Diah Handayani Tarigan ${ }^{1}$, \\ Leni Andriana ${ }^{1}$, and Risna ${ }^{1}$ \\ ${ }^{1}$ Postgraduate of Universitas Muslim Nusantara Al Washliyah Medan, Indonesia \\ ${ }^{2}$ Lecturer of Universitas Muslim Nusantara Al Washliyah Medan, Indonesia \\ *Corresponding author email: sutikno@umnaw.ac.id
}

\begin{abstract}
This research is aimed in explaining the effect of practical methods in writing complex procedural text for eleventh grade students of Swasta Swadaya Hamparan Perak Senior High School 2020-2021 Academic Year. The population of this research were all students of eleventh grade of Swasta Swadaya Hamparan Perak Senior High School totaling 32 students. The samples in this research all 32 students. The method used in this research is an experimental method with the one group pretest posttest model. The instrument used to collect data was an essay test in the form of an assignment, namely writing complex procedural text. Hypothesis testing is done using the t-test. The results showed that the students' ability in writing complex procedural texts without any treatment with the practical method was in the enough category with an average score of 68.1, while after the practice method was included in the good category with an average score of 79.5. Furthermore, hypothesis testing shows t-count $>\mathrm{t}$-table, that is $4.45>2.04$ at the significant level $\alpha=0.05$. Thus, it has been proven that the null hypothesis (Ho) is rejected and the alternative hypothesis (Ha) is accepted, namely that the practice method is more influential in increasing the ability to write complex procedural text for students of Swasta Swadaya Hamparan Perak Senior High School 2020-2021 Academic Year.
\end{abstract}

Keywords: Practical Methods, Writing, Complex Procedure Text

\section{INTRODUCTION}

Writing is the activity most often carried out by students in school because all lessons must use writing as a means of transferring information. Therefore, writing is an important tool in the teaching and learning process, including learning Indonesian [1]-[3].

This is reinforced by the opinion of Tarigan [4], which suggests that the role of writing in the world of education are: (1) making it easier for students to think critically; (2) feel students feel and enjoy relationships; (3) deepen the ability to catch or perceive students; and (4) explain thoughts, ideas or ideas. From Tarigan's opinion, that the ability to write for students is very important, but teaching writing in schools is often not balanced with language teaching, so that writing skills are not optimal.

Language skills are usually only emphasized on linguistic knowledge and lack of training so that students' writing results are not good, it can be seen from the many choices of inaccurate words, ineffective sentences, difficulty expressing ideas, difficulty making sentences, and being 
unable to develop ideas regularly and systematically [5][7].

One of the various types of text is complex procedure text. According to Kosasih [8], a complex procedure text is a text that explains the complete, clear, and detailed steps on how to do something, which in this case is about effective learning methods or tricks.

Based on observations at Swasta Swadaya Hamparan Perak Senior High School, the ability to write complex procedural texts in its implementation is still not optimal. This is due to the lack of student interest in writing complex procedural text, the low ability of students to write complex procedure text, the lack of vocabulary, students are able to read but have difficulty writing complex procedural text, and students have difficulty developing ideas in writing complex procedural text [9][11].

Besides students having difficulty in writing, in learning to write, especially in writing complex procedural texts, the teacher often only comes from one Indonesian text book, and does not provide references or examples of complex procedural texts from other sources. When in the field the teacher instructs students to write text without giving examples of what they should note so that students feel they don't understand and end up lazy. Assumptions like that ultimately reduce students to write.

It takes proper writing skills to improve students' writing skills, especially writing complex procedural texts. Complex procedure text is a text consisting of steps or steps to do something. This text has a logical and orderly sequence for each step. Complex procedure texts compose something that will be presented sequentially or regularly in their implementation. This type of text is used when creating or doing something. A complex procedural text usually has a purpose, material and steps in its implementation.

As a prospective educator, the researchers must be able to solve problems that cause them difficulty in expressing these ideas. There are many ways that can be done so that students have the ability to write. One of them is by using practical methods. According Istarani [3], the practical method is a way of presenting subject matter with direct physical and mental involvement (direct practice) in the teaching and learning process, starting from the preparation of practical tools, instructions for using practical tools, giving examples to practice and so on until conclusion.

Faturrahman and Sutikno [4] state that the use of practical methods is intended to educate by providing educational materials using either tools or objects, and to display them, with the hope that students will be clear and easy as well as be able to practice the material in question.

The practical method is a teaching method where students carry out practical training activities so that students have higher assertiveness or skills than what has been learned. The use of practical methods in learning to write complex procedural texts because through practical activities, students get a way of presenting subject matter with direct physical and mental involvement in the teaching and learning process, starting from the preparation of practical tools, instructions for using practical tools, giving examples to practice and so on, came to a conclusion.

\section{METHODOLOGY}

\subsection{Effectiveness}

This research will be conducted at Swasta Swadaya Hamparan Perak Senior High School, which is located at Jl. Limo Miri Bulu Cina, Hamparan Perak Subdistrict, Deli Serdang Regency. This research will be carried out in semester of 2020-2021 academic year. The population of this study were all students of Swasta Swadaya Hamparan Perak Senior High School totaling 32 students.

The method used in this research is an experimental method with the one group pretest posttest model. The instrument used to collect data was an essay test in the form of an assignment, namely writing complex procedural texts. Hypothesis testing is done using the $\mathrm{t}$ test.

After all the data is collected, it will then be analysed in order to achieve maximum results. The steps for the analysis can be done in the following ways.

1. Arrange value data before being given treatment and after being given treatment in tabular form.

2. Calculating the average value and standard deviation of sample data, namely data before being given treatment and data after being given treatment

3. To calculate the average, use the following formula:

$$
M_{X}=\frac{\Sigma f x}{N} .
$$

4. Calculating the standard deviation with the following formula:

$$
S D_{x}=\sqrt{\frac{\Sigma f x^{2}}{N}} .
$$

5. Test data analysis requirements.

Normality Test. After the research data is collected, the data will be analyzed by means of a normality test using the Liliefors test.

Homogeneity Test. The homogeneity test is about the variants of two or more distributions. The homogeneity test was conducted to determine whether the data for variable $\mathrm{X}$ and variable $\mathrm{Y}$ were homogeneous or not. To find out whether the data from the experimental class has homogeneous variants or not, the two variants similarity test is carried out with the formula:

$$
F_{\text {count }}=\frac{S_{1}^{2}}{S_{2}^{2}}
$$

The homogeneity test is carried out with the following criteria. Ho is accepted if F-count < F-table and Ho is rejected if F-count $>$ F-table which states that the sample comes from a homogeneous population.

Hypothesis Testing. Based on the normality test and homogeneity test in the experimental class, if the results show the data is normally distributed and homogeneous. This shows that the requirements of this research analysis are met, so that further testing can be continued, namely 
hypothesis testing with the t-test, with the following formula:

$$
t_{o}=\frac{M_{1}-M_{2}}{S E_{M_{1}-M_{2}}} .
$$

Accordingly, if $t_{o}<t_{t}$ on the real level $\alpha=0.05$ then Ho accepted and Ha rejected, otherwise if $t_{o}>t_{t}$ on the real level $\alpha=0.05$ then Ho rejected and Ha accepted.

\section{RESULTS AND DISCUSSION}

Table 1 present a comparison of pre-test and post-test assessment results.

Table 1. Comparison of Pre-test and Post-test Assessment

\begin{tabular}{|c|c|c|c|}
\hline \multicolumn{4}{|c|}{ Results } \\
\hline No & Student Name & Pre-test & Post-tes \\
\hline 1 & Alfiana Regina & 55 & 70 \\
\hline 2 & Ayu Wulandari & 60 & 70 \\
\hline 3 & Aziz Ar - Rasyid & 80 & 95 \\
\hline 4 & Davina & 65 & 70 \\
\hline 5 & Dessy Nirvan & 70 & 95 \\
\hline 6 & Diana Safitri & 80 & 80 \\
\hline 7 & Dilla Pratiwi & 65 & 75 \\
\hline 8 & Dimas Pradana & 70 & 95 \\
\hline 9 & Doni Sapriadi & 70 & 90 \\
\hline 10 & Dwi Ayunda & 60 & 85 \\
\hline 11 & Dwi Lestari & 55 & 65 \\
\hline 12 & Elisa Anggriani & 80 & 60 \\
\hline 13 & Ely Febriyani & 80 & 85 \\
\hline 14 & Fajar Perdana & 45 & 80 \\
\hline 15 & Irvan Kurniawan & 75 & 90 \\
\hline 16 & Kinanti Kesuma & 60 & 70 \\
\hline 17 & Lola Ladillah & 65 & 70 \\
\hline 18 & Maiyasa Saputri & 65 & 80 \\
\hline 19 & Mei Dina Utari & 75 & 90 \\
\hline 20 & Najiyyullah & 65 & 80 \\
\hline 21 & Putri Andini & 60 & 80 \\
\hline 22 & Putri Intan & 50 & 80 \\
\hline 23 & Putri Yulia & 90 & 65 \\
\hline 24 & Resa Amelia & 80 & 85 \\
\hline 25 & Rifi Hamdani & 85 & 85 \\
\hline 26 & Risty Andriyani & 65 & 90 \\
\hline 27 & Salsa Tri Nanda & 65 & 85 \\
\hline 28 & Serli Afriyanti & 75 & 80 \\
\hline 29 & Serly Anggraini & 65 & 65 \\
\hline 30 & Shelly Putri & 75 & 90 \\
\hline 31 & Suci Ramadhani & 65 & 80 \\
\hline 32 & Tedi Prayoga & 65 & 65 \\
\hline & Total & 2180 & 2545 \\
\hline & Average & 68.1 & 79.5 \\
\hline
\end{tabular}

From the comparison table before and after applying the practical method above we can see the comparison of the scores of each student. Of the 32 students, only 1 student experienced a lack of grades than before and 4 students got a fixed grade, the rest experienced an increase. The increase also occurred in the stage before the application of the direct practice method which was categorized sufficient with an average value of 68.1 compared to the stage after the application of the practical method which was categorized as good with an average value of 79.5. This means that the media used in teaching writing text complex procedures are very influential.

\subsection{Normality Test}

One of the requirements in the data that must be met in order to use parametric statistics is that the distribution of variable data must be normally distributed. To find out whether the distribution of data is normal or not, you can use the Liliefors test. The normal conditions that must be met are the L-count $<$ L-table at the significant level $\alpha=$ 0,05 . The following is the data table for normality test of $\mathrm{X} 1$.

It is known that the pre-test mean equal to 68.1 , standard deviation equal to 9.47 , standard error equal to 1.70 , and $\mathrm{N}$ equal to 32 .

Standard Numbers:

$$
\begin{aligned}
Z_{i} & =\frac{X-\bar{X}}{S D}=\frac{45-68.1}{9.47}=-2.43 \\
S\left(Z_{i}\right) & =\frac{f K u m}{N}=\frac{1}{32}=0.03 \\
|L| & =\left|F\left(Z_{i}\right)-S\left(Z_{i}\right)\right|=|0.00075-0.003| \\
& =|-0.0225|=0.0225 .
\end{aligned}
$$

Based on the Table 2, it can be obtained that the value of $\mathrm{L}$-count $=0.070$, from the critical table $\mathrm{L}$ for the Liliefors test with $\mathrm{N}=32$ and the real level $\alpha=0.05$ can get L-table $=0.156$. After being compared, it turns out that L-count < L-table, that is $0.070<0.156$. So, it can be concluded that $\mathrm{X} 1$ variable data is normally distributed.

The following is the post-test (X2) data for normality test using the Liliefors test.

It is known that the pre-test mean equal to 79.5 , standard deviation equal to 10.72 , standard error equal to 1.92 , and $\mathrm{N}$ equal to 32 .

Standard Numbers:

$$
\begin{aligned}
Z_{i} & =\frac{X-\bar{X}}{S D}=\frac{60-79.5}{10.72}=-1.82 \\
S\left(Z_{i}\right) & =\frac{f K u m}{N}=\frac{1}{32}=0.03 \\
L & =F\left(Z_{i}\right)-S\left(Z_{i}\right)=0.0344-0.03=0.0044 .
\end{aligned}
$$

Based on the Table 3, it can be obtained that the value of harga L-count $=0.120$, from the critical table $\mathrm{L}$ for the Liliefors test with $\mathrm{N}=32$ and the real level $\alpha=0.05$, can get L-table $=0.156$. After comparing it, it turns out that Lcount < L-table, that is $0.120<0.156$. So, it can be concluded that $\mathrm{X} 2$ variable data is normally distributed.

\subsection{Homogeneity Test}

To test the homogeneity of the data using the F-test from Havley. The calculation can be done as follows

$$
F_{\text {count }}=\frac{S_{1}^{2}}{S_{2}^{2}}=\frac{115}{89.86}=1.27 \text {. }
$$

The test criterion is Ho is accepted if F-count < F-table is taken $\mathrm{dk}$ the numerator is $\mathrm{dk}$ the largest variance and $\mathrm{dk}$ denominator is $\mathrm{dk}$ the smallest variance. 
Table 2. Pre-test Data Normality Test (X1)

\begin{tabular}{cccccccc}
\hline No & $\mathrm{X}$ & $\mathrm{F}$ & $\mathrm{F}$. Kum & $\mathrm{Zi}$ & $\mathrm{F}(\mathrm{Zi})$ & $\mathrm{S}(\mathrm{Zi})$ & $\mathrm{L}$ \\
\hline 1 & 45 & 1 & 1 & -2.43 & 0.0075 & 0.03 & 0.022 \\
2 & 50 & 1 & 2 & -1.91 & 0.0281 & 0.06 & 0.031 \\
3 & 55 & 2 & 4 & -1.38 & 0.0838 & 0.12 & 0.036 \\
4 & 60 & 4 & 8 & -0.85 & 0.1977 & 0.25 & 0.052 \\
5 & 65 & 10 & 18 & 0.33 & 0.6293 & 0.56 & 0.069 \\
6 & 70 & 3 & 21 & 0.20 & 0.5793 & 0.65 & 0.070 \\
7 & 75 & 4 & 25 & 0.73 & 0.7673 & 0.78 & 0.012 \\
8 & 80 & 5 & 30 & 1.25 & 0.8944 & 0.94 & 0.045 \\
9 & 85 & 1 & 31 & 1.78 & 0.9625 & 0.97 & 0.007 \\
10 & 90 & 1 & 32 & 2.31 & 0.9896 & 1.00 & 0.010 \\
\hline & & 32 & & & & &
\end{tabular}

Table 3. Post-test Data Normality Test (X2)

\begin{tabular}{ccccclcl}
\hline No & X & F & F. Kum & $\mathrm{Zi}$ & $\mathrm{F}(\mathrm{Zi})$ & $\mathrm{S}(\mathrm{Zi})$ & $\mathrm{L}$ \\
\hline 1 & 60 & 1 & 1 & -1.82 & 0.0344 & 0.03 & 0.004 \\
2 & 65 & 4 & 5 & -1.35 & 0.0885 & 0.15 & 0.061 \\
3 & 70 & 5 & 10 & -0.88 & 0.1894 & 0.31 & 0.120 \\
4 & 75 & 1 & 11 & -0.42 & 0.3372 & 0.34 & 0.002 \\
5 & 80 & 8 & 19 & 0.05 & 0.5199 & 0.59 & 0.070 \\
6 & 85 & 5 & 24 & 0.51 & 0.6950 & 0.75 & 0.055 \\
7 & 90 & 5 & 29 & 0.98 & 0.8365 & 0.90 & 0.063 \\
8 & 95 & 3 & 32 & 1.44 & 0.9251 & 1.00 & 0.074 \\
\hline \multicolumn{7}{c}{32} \\
\hline
\end{tabular}

Then obtained F-count $=1.27$ with $\mathrm{dk}$ numerator and denominator 32 from the distribution table $\mathrm{F}$ for $\alpha=0.05$ obtained F-table for $\mathrm{dk}$ numerator and denominator 32, that is F-table $=1.82$. So, F-count $<$ F-table, that is $1.27<$ 1.82. This proves that the sample Ho which states that the variance of the two variables is homogeneous.

\section{3. Hypothesis Testing}

After testing for normality and homogeneity, it turns out that the two variables are normally distributed and have the same variance (homogeneous). Thus, the use of the ttest statistic can be done with the following formula:

$$
t_{0}=\frac{M_{2}-M_{1}}{S E_{M_{2}-M_{1}}}=\frac{79.5-68.1}{2.56}=\frac{11.4}{2.56}=4.45,
$$

where

$$
\begin{gathered}
S E_{M_{2}-M_{1}}=\sqrt{\left(S E_{M_{2}}\right)^{2}+\left(S E_{M_{1}}\right)^{2}}=\sqrt{(1.92)^{2}+(1.70)^{2}} \\
=\sqrt{3.69+2.89}=\sqrt{6.58}=2.56 .
\end{gathered}
$$

After $t_{o}$ is obtained, then we consult with table $t$ at $5 \%$ level with $\mathrm{dk}=31$. In table $\mathrm{t}$ with $\mathrm{dk}=31$, it is obtained a significant level of 5\%, $\alpha=2.04$. Because $t_{o}$ obtained is greater than t-table, that is $4.45>2.04$, the null hypothesis (Ho) is rejected and the alternative hypothesis (Ha) is accepted.

This proves that the practice method has an influence in improving the ability to write complex procedural text for eleventh grade students of Swasta Swadaya Hamparan Perak 2020-2021 Academic Year.

\section{CONCLUSION}

Based on the results of the discussion described, the following conclusions can be drawn.

1. The average value of the ability to write complex procedure text for students of Swasta Swadaya Hamparan Perak Hamparan Perak Senior High School for 2020-2021 academic year before using the practical method is 68.1 in the moderate category with the highest score of 90 and the lowest score of 45 .

2. The average value of the ability to write complex procedural text Swasta Swadaya Hamparan Perak Hamparan Perak Senior High School for 2020-2021 academic year bafter using the practical method is 79.5 in the good category with the highest score of 95 and the lowest score of 60 .

3. There is an effect in applying practical methods in the ability to write complex procedural texts. It can be seen from the results of the research conducted, namely the results of the pre-test and post-test, and the results of the t-test, obtained t-count $>\mathrm{t}$-table, that is $4.45>2.04$. This shows that the practical method has an influence in learning to write complex procedural texts. 


\section{REFERENCES}

[1] I. K. Nurhayati, S. Noviaristanti, T. Priyanto. Indonesian Employees' Writing Skills, Linguistic Intelligence, and Critical Thinking Levels. 3rd International Seminar and Conference on Learning Organization, (2015), 1-6.

[2] L. Mulyani, D. Solihat, I. Hanifah, The Influence of Picture and Picture Model on Indonesian Writing Skills. Indonesian Journal of Learning and Instruction, 1 (2) (2018), 33-38.

[3] H. Muliawati, B. Nurzaman, N. Oktaviani, Meningkatkan Keterampilan Menulis Teks Deskripsi. Indonesian Language Education and Literature, 3 (2) (2018), 157-170.

[4] H. G. Tarigan, Menulis sebagai Suatu Keterampilan Berbahasa. Bandung: Angkasa, 2005.

[5] N. K. D. Tristiantari, An Effect of Sociodrama Method Implementation in Students Language Skill at Fourth Grade Elementary School in Cluster XII of Buleleng District. Journal of Education Technology, 1 (1) (2017), 45-50.

[6] S. A. Indrowaty, The Children's Language Skill of Indonesia and Javanese. Erudio Journal of Educational Innovation, 5 (2) (2018), 22-35.

[7] Haerazi, L. A. Irawan, Developing Intercultural Language Learning (ILL) model to teach writing skills at Indonesian private universities. Journal of English Education, Literature, and Culture, 5 (1) (2020), 43-54.

[8] Kosasih, Jenis-Jenis Teks. Bandung: Yrama Widya, 2014.

[9] E. P. Prasetya, The Use of Cooking Video to Improve Students' Writing Skill on Procedure Text. English Journal, 20 (1) (2017), 25-33.

[10] S. Aminah, The Use of Video in Teaching Writing Procedure Text. NOBEL: Journal of Literature and Language Teaching, 9 (2) (2018), 148-157.

[11] T. K. Putri, S. Saun, An Analysis of The Second Year Students' Ability in Writing A Procedure Text of a Recipe at SMK N 9 Padang. Journal of English Language Teaching, (8) (3) (2018), 336-343.

[12] Istarani, Kumpulan 39 Metode Pembelajaran. Medan: Iscom, 2018.

[13] P. Faturrahman, M. S. Sutikno, Strategi Belajar Mengajar. Bandung: Refika Aditama, 2007.
[14] F. A. Cahyo, A. Farizka, A. Amiruddin, R. H. Musa, Practical Method of Predicting Slope Failure Based on Velocity Value (SLO Method) From Slope Stability Radar. PROSIDING XXVII DAN KONGRES X PERHAPI, (2018), 143-150.

[15] M. E. Safitri, K. I. Ahmad, M. Saleh, Development of Child Independence Through Model Picture and Picture, Examples Non-Examples Model and Practical Method Directly Activities of Learning Practical Life in Group B Kasih Ibu Kindergarten, Banjarmasin, Indonesia. European Journal of Education Studies, 5 (7) (2018), 64-80.

[16] P. W. Hastuti, V. A. Tiarani, T. Nurita, The Influence of Inquiry-Based Science Issues Learning on Practical Skills of Junior High School Students in Environmental Pollution Topic. Jurnal Pendidikan IPA Indonesia, 7 (2) (2018), 232-238. 